\title{
PENGEMBANGAN MEDIA PUTAR NUSANTARA PADA MATERI KERAGAMAN PAKAIAN ADAT DI INDONESIA UNTUK KELAS IV SD
}

\author{
Oleh: \\ Devia Luthfi Oktaviani, Sumardi \& Akmad Nugraha \\ Jurusan Pendidikan Guru Sekolah Dasar, Jurusan Pendidikan \\ Ilmu Sosial, Jurusan Ilmu Pendidikan, Universitas Pendidikan \\ Indonesia
}

Email: devialuthfii@student.upi.ed

\begin{abstract}
Abstrak
Penelitian pengembangan ini bertujuan untuk menghasilkan media Papan Putar Nusantara pada pembelajaran IPS kelas IV SD Negeri Cijoho dan SDN 2 Kiarajangkung Kecamatan Sukahening, Kabupaten Tasikmalaya. Media Papan Putar Nusantara ini dibutuhkan untuk mengakomodir kebutuhan pembelajaran IPS akan media belajar. Penelitian pengembangan ini menggunakan metode penelitian Design Based Research. Langkah-langkah dalam penelitian ini menggunakan model Reeves dalam Pool \& Laubscher, meliputi (1) identifikasi dan analisis masalah oleh peneliti dan praktis secara kolaboratif, (2) mengembangkan solusi yang didasakan patokan teori, design principle yang ada dan inovasi teknologi, (3) melakukan proses berulang untuk menguji dan memperbaiki solusi secara praktisi dan (4) refleksi untuk menghasilkan design principle serta meningkatkan implementasi dari solusi secara praktis. Pengembangan produk divalidasi oleh ahli materi dan ahli media. Teknik pengambilan data pada penelitian ini adalah purposive sampling. Produk media berupa papan putar nusantara adalah papan lingkar yang berputar didalamnya terdapat angka sebagai titik tumpu untuk menentukan hasil dari keterangan pada suatu daerah untuk mengetahui tujuan pembelajaran dengan permainan. Media pembelajaran menjadi faktor untuk meningkatkan pemahaman peserta didik sebagai proses belajar mengajar akan elbih efektif dan menyenangkan sehingga guru membantu mencari pesan dari bahan pembelajaran kepada peserta didik.
\end{abstract}


Kata kunci: Media, Permaian Papan Putar, Pakaian Adat Indonesia, Kelas IV Sekolah Dasar

\begin{abstract}
This development research aims to produce Nusantara Playboard media in social studies class IV SD Negeri Cijoho and SDN 2 Kiarajangkung, Sukahening District, Tasikmalaya Regency. This Nusantara Playboard media is needed to accommodate the social studies learning needs of learning media. This research uses the Design Based Research research method. The steps in this study use the Reeves model in Pool \& Laubscher, including (1) identifying and analyzing problems by researchers and collaboratively practicing, (2) developing solutions based on theoretical standards, existing design principles and technological innovation, (3) carry out an iterative process to test and improve solutions practically and (4) reflection to produce a design principle and improve the practical implementation of the solution. Product development is validated by material experts and media experts. The data collection technique in this study was purposive sampling. The media product in the form of an archipelago rotary board is a circular board that rotates in which there are numbers as a fulcrum for determining the results of information in an area to determine the objectives of learning with games. Learning media is a factor in increasing students' understanding as the teaching and learning process will be more effective and fun so that teachers help find messages from learning materials to students.
\end{abstract}

Keywords: Media, play board games, Indonesian customs clothes, social studies in elementary school 


\section{Pendahuluan}

Pendidikan adalah usaha sadar dan terencana untuk mewujudkan suasana belajar dan proses pembelajaran agar peserta didik secara aktif mengembangkan potensi dirinya untuk memiliki kekuatan spiritual keagamaan, pengendalian diri, kepribadian, kecerdasan, akhlak mulia, serta keterampilan yang diperlukan dirinya, masyarakat, bangsa dan negara. Pendidikan dapat diartikan sebagai suatu usaha yang disadari, disengaja, dan disiapkan dalam mencapai tujuan dalam proses pembelajaran. Pendidikan sebagai kunci untuk kemajuan dan perkembangan sumber daya manusia yang berkualitas. Pendidikan berperan penting untuk membangun karakter bangsa, melalui pendidikan manusia dapat mewujudkan semua potensi yang dimilikinya.

Pendidikan formal di sekolah merupakan salah satu bentuk pendidikan yang umumnya dialami oleh manusia. Utamanya dalam perannya sebagai warga negara dalam kehidupan berbangsa dan bernegara. Sesuai tujuan Pendidikan yang tercantum dalam UU No. 20 Tahun 2003 pasal 3 Tentang Sistem Pendidikan Nasional, harapannya siswa dapat tumbuh menjadi manusia yang warga negara yang beriman dan bertakwa kepada Tuhan Yang Maha Esa, berakhlak mulia, sehat, berilmu, cakap, kreatif, mandiri, dan menjadi warga negara yang demokratis serta bertanggung jawab.

Sebagai bagian dari masyarakat dan warga negara Indonesia, salah satu wawasan yang perlu dipahami dengan baik oleh siswa adalah wawasan mengenai sejarah bangsa Indonesia, keanekaragaman budaya masyarakat Indonesia, dan pentingnya merawat persatuan diatas perbedaan-perbedaan yang ada. Salah satu upaya yang dilakukan di jenjang pendidikan dasar adalah 
melalui mata pelajaran IPS yang diajarkan di tingkat Pendidikan dasar baik Sekolah Dasar (SD) maupun Sekolah Menengah Pertama (SMP).

Ilmu Pengetahuan Sosial (IPS) merupakan bidang studi yang mempelajari, menelaah, dan menganalisis gejala dan masalah social di masyarakat yang ditinjau dari berbagai aspek kehidupan secara terpadu (Sapriya, Istanti, \& Zulkifli, 2007:5). Fakih \& Bunyamin (1999: 1) menyatakan bahwa IPS merupakan mata pelajaran yang memadukan konsep-konsep dasar dari berbagai ilmu sosialdisusun melalui pendidikan dan psikologis serta kelayakan dan kebermaknaannya bagi siswa dan kehidupannya.

Menurut Sapriya (2009: 20) Istilah IPS di sekolah dasar merupakan nama mata pelajaran yang berdiri sendiri sebagai integrasi dari sejumlah konsep disiplin ilmu sosial, humaniora, sains bahkan berbagai isu dan masalah sosial kehidupan. Materi IPS untuk jenjang sekolah dasar tidak terlihataspek disiplin ilmu karenalebih dipentingkan adalah dimensi pedagogik dan psikologis serta karakteristik kemampuan berpikir peserta didik yang bersifat holistik Sapriya (2009: 20)

Sepertihalnya umumnya materi pembelajaran di sekolah, untuk menunjang pemahaman siswa tentang konsep keanekaragaman budaya masyarakat Indonesia guru perlu menciptakan pengalaman pembelajaran yang baik. Pengalaman belajar yang baik salah satunya ditunjang oleh adanya media pembelajaran. Untuk itu guru perlu melakukan pemilihan media pembelajaran yang tepat. Penggunaan media pendidikan secara tepat dan bervariasi dapat merangsang keaktifan siswa. Dalam hal ini media pembelajaran berguna untuk menimbulkan kegairahan belajar, memungkinkan interaksi yang lebih 
langsung antara siswa dengan lingkungan kenyataan; Memungkinkan peserta siswa sendiri-sendiri menurut kemampuan dan minatnya.

Sayangnya menggunakan media pembelajaran khsusnya pembelajaran IPS masih banyak mengalami kelambatan. Bentukbentuk media yang umumnya digunakan adalah buku, atlas, globe, peta, atau poster. Media belajar ini bisa jadi tepat digunakan untuk materi-materi tertentu, namun kurang tepat digunakan untuk materi-materi lain. Sebagai contoh, media pembelajaran globe, atlas, dan peta tentu sesuai bagi materi ajar mengenai letak dan karakteristik fisik wilayah, namun tidak sesuai untuk menjelaskan keragaman budaya masyarakat Indonesia.

'Media' adalah kata dalam bahasa latin, bentuk jamak dari kata 'medium' yang berarti pengantar atau perantara. Dari pemahaman ini dapat dikatakan bahwa media adalah pengantar pesan. Dalam konteks pembelajaran di kelas media belajar dikatakan oleh Ely dalam Rudy \& Hisbiyatul (2017: 9) sebagai alat-alat grafis, forografis, atau elektronis untuk menangkap, memproses dan menyusun Kembali informasi visual dan verbal. Martin dan Briggs dalam Rudy \& Hisbiyatul (2017: 9-10) menjelaskan bila media pembelajaran meliputi semua sumber yang diperlukan untuk melakukan komunikasi dengan pembelajar. Bentuknya bisa berupa perangkat keras dan perangkat lunak yang digunakan pada perangkat keras. Malik dalam Rudy \& Hisbiyatul (2017:10) berpendapat bila media pembelajaran adalam segala sesuatu yang dapat digunakan untuk menyalurkan pesan (materi ajar) sehingga dapat merangsang perhatian, minat, dan perasaan siswa dalam kegiatan belajar untuk mencapai tujuan tertentu. 
Dale seperti dikutip oleh Dendi \& Sukirno (2015) menyatakan "kurang lebih 75\% hasil belajar seseorang diperoleh melalui indera pandang, melalui indera dengar sekitar 13\% dan melalui indera lainnya sekitar 12\%”. Denganmembaca hasil tersebut, dapat disimpulkan bahwa media pembelajaran sangat berperan dalam proses belajar siswa. Hal ini dikarenakan media mampu memvisualisasikan konsep yang abstrak ke dalam bentuk visual yang dapat diamati oleh indera pandang. Berdasarkanpenjelasan ini dapat dikatakan bahwa pada pembelajaran IPS tidak hanya memerlukan satu atau dua bentuk media pembelajaran, namun sangat banyak dan beragam, agar bisa disesuaikan dengan kebutuhan materi, suasana kelas, jumlah siswa, dan lain sebagainya.

Merujuk pada penjelasan di atas, maka idealitas media pembelajaran IPS haruslah bisa digunakan sebagai sarana penyampaian materi dan menarik perhatian siswa. Untuk itu perlu upaya pengembangan media pembelajaran yang lebih akomodatif terhadap tuntutan pembelajaran IPS yang menekankan kontekstulaitas.

Keterbatasan media pembelajaran IPS menjadikan proses pembelajaran terlalu terpusat pada guru. Sumber informasi akan materi mengarah pada apa yang guru sampaikan. Terpusatnya penjelasan materi dari guru saja menyebabkan pembelajaran kurang menarik, siswa tidak bisa memahami pembelajaran secara optimal, dan tidak bertindak aktif untuk mencari materi dan membangun pemahamannya sendiri.

Media buku, atlas, globe, peta, atau poster tersebut bersifat kurang konkret dan kurang mengakomodir pengalaman belajar siswa. Pada materi yang berkaitan dengan keragaman budaya seperti pakaian adat nusantara, diharapkan guru dapat 
menyajikan materi ajar dengan media pembelajaran yang sesuai, yang dapat menunjukkan konten materi secara jelas.

Dari latar belakang terserbut peneliti memandang perlu ada inovasi pengembangan media pembelajaran yang lebih sesuai dengan setiap materi pembelajaran IPS, didukung dengan metode pempelajaran yang bisa menitikberatkan pada aktivitas siswa di kelas. Peneliti menggagas pengembangan media pembelajaran berupa permainan Papan Putar Nusantara sebagai alternatif media pembelajaran pada materi keragaman pakaian adat di Indonesia pada mata pelajaran IPS di kelas IV Sekolah Dasar. Media Papan Putar Nusantara ini dikembangkan dengan menonjolkan gambar nyata pakaian-pakaian adat dari daerahdaerah di Indonesia, sehingga diharapkan bisa menciptakan pembelajaran IPS yang optimal di kelas-kelas.

\section{Metode Penelitian}

Penelitian ini adalah penelitian pengembangan yang dilakukan dengan metode Design Based Research (DBR), dengan Langkah-langkah pengembangan dalam penelitian merujuk pada model yang dikembangkan oleh Reeves. Langkah pengembangan yang dilakukan meliputi (1) Identifikasi dan analisis masalah oleh peneliti dan praktis secara kolaboratif, (2) mengembangkan solusi yang didasarkan pada teori, prisip desain yang ada dan inovasi teknologi, (3) melakukan proses berulang untuk menguji dan memperbaiki solusi secara praktisi dan (4) refleksi untuk menghasilkan design principle serta meningkatkan implementasi dari solusi secara praktis.

Upaya guru dalam mengkonkretkan materi-materi IPS yang abstrak dapat dibantu melalui media pembelajaran. Pemanfaatan media pembelajaran yang melibatkan pengalaman langsung akan 
membangun pengalaman dan makna belajar yang lebih kuat. (Setiawati, Pranata, \& Halimah, 2019). Adapun alur model Reeves adalah sebagai berikut:

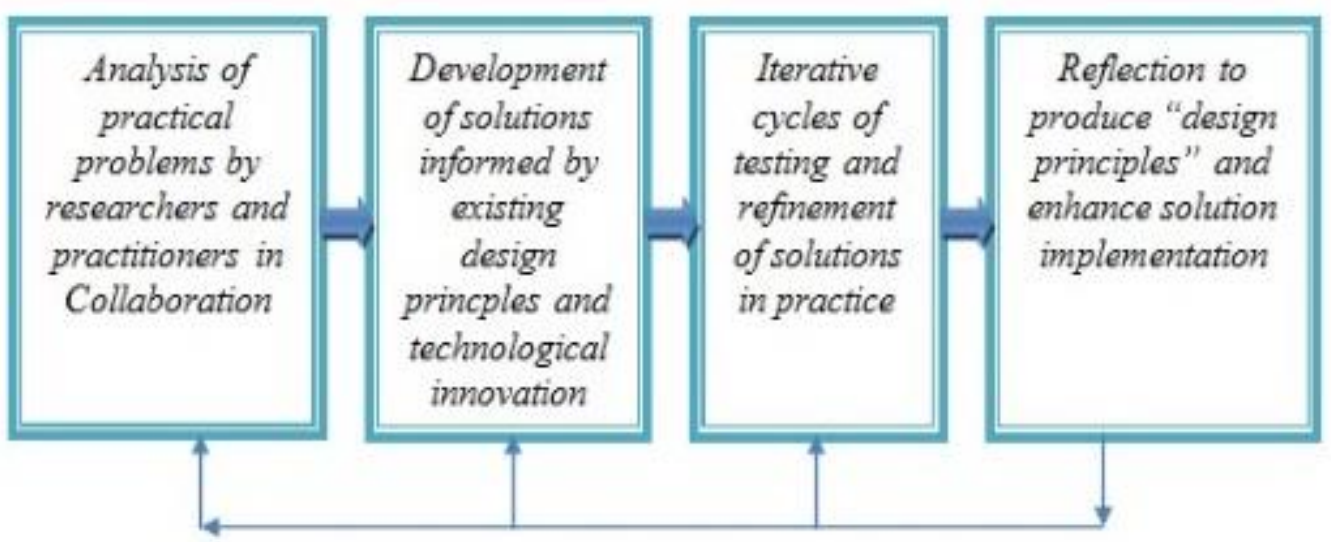

Refinement of Problems, Solustions, and Methods, and Design Principles

Gambar 1

Diagram Design Based Model Reeves

Pada penelitian kualitatif seperti penelitian tindakan kelas, etnografi, fenomenologi, atau studi kasus, perlu ditambahkan kehadiran peneliti, subyek penelitian, informan yang ikut membantu beserta cara-cara menggali data-data penelitian, lokasi dan lama penelitian serta uraian mengenai pengecekan keabsahan hasil penelitian.

Teknik pemilihan media pembelajaran menggunakan model pemilihan Anderson. Teknik pengambilan data pada penelitian ini adalah purposive sampling, teknik sampel ini termasuk ke dalam nonprobability sampling, artinya pengumpukan data melibatkan orang-orang tertentu sebagai kebutuhan peneliti. Untuk memenuhi kebutuhan peneliti yaitu guru kelas IV Sekolah Dasar, ahli materi IPS dan Media. Pengumpulan data penelitian ini menggunakan teknik wawancara, observasi, dan validator Ahli materi dan media. 


\section{Hasil Penelitian}

Berdasarkan hasil wawancara dilakukan kepada dua guru sebagai narasumber, ditemukan permasalahan pada media Pembelajaran IPS khususnya materi keragaman pakaian adat di Indonesia. Masalah yang dimaksud adalah media pembelajaran masih kurang megakomodir kebutuhan pembelajaran. Harapan dari guru adalah tersedianya media pembelajaran yang menarik perhatian siswa, menjadi sarara terjadinya pembelajaran yang interaktif, serta memicu kreatifitas siswa. Melalui pembelajaran yang menari dan interaktif, harapannya bisa menarik perhatian peserta didik dalam pembelajaran, sehingga materi yang diberikan mudah diterima oleh peserta didik dan tujuan pembelajaran tercapai. Media pembelajaran juga diharapkan merupakan media yang bersifat tahan lama, bisa dipakai secara berulang-ulang, sehingga dan lebih bermanfaat dan bertahan lama.

Sebagai alternatif solusi, peneliti mengembangkan media permainan papan putar Nusantara. Proses pengembangan disesuaikan dengan Kompetensi Dasar, Indikator, tujuan dan materi yang akan disampaikan. Proses pengembangannya meliputi perencanaan dan pengembangan produk.

Serangkaian proses pengembangan media pembelajaran dimulai dari, pertama, peneliti mengumpulkan data dengan cara observasi dan wawanca pada guru dan siswa tentang permasalahan yang dihadapi sehari-hari dalam pembelajaran IPS di kelas. Pengumpulan data dilakukan di kelas IV Sekolah Dasar SDN 2 Kiarajangkung dan SDN Cijoho. Setelah wawancara dilakukan, peneliti kemudian melakukan validasi dari ahli materi, ahli media dan validasi kepada pedagogik atau guru. 
Kedua, Perencanaan. Perencanaan pengembangan produk dimulai dengan memilih konten materi pembelajaran yang memerlukan media ajar. Setelah dilakukan kajian dan diskusi dengan guru di sekolah, maka tema yang dipilih dalam pengembangan media pembelajaran ini adalah Indahnya Keragaman di Negeriku, dengan materi Keragaman Suku Bangsa di Indonesia, tentang Keragaman Pakaian Adat di Indonesia.Kemudian dipetakan materi apa saja yang dituangkan dalam media. Pada pengembangan media ini materi yang dituangkan dalam media adalah keragaman pakaian adat meliputi macam-macam pakaian adat dari berbagai daerah beserta nama dan teks keterangannya.

Ketiga, adalah tahap pengembangan bentuk produksi. Pada tahap ini peneliti membuat media serta memvalidasi media dan materi kepada ahli. Media yang dibuat adalah berupa papan putar berbentuk lingkaran. Bahan inti pembuatannya adalah dari kardus dan duplek berlapis kertas warna warni untuk menempel tulisan dan sebagai keterangan dari tantangan yang akan diberikan.

Papan putar berbentuk lingkaran, dengan ukuran panjang area putar berdiameter $30 \mathrm{~cm}$. Kartu bergambar pakaian adat menggunakan kertas ivory ukuran $7 \mathrm{~cm} \times 10 \mathrm{~cm}$. Terdapat alas dengan ukuran $120 \mathrm{~cm}$ x $80 \mathrm{~cm}$ dengan terdapat angka untuk tantangan dengan pola melingkar. Kemudian terdapat amplop warna warni yang ditandai dengan angka sebagai ciri dari setiap amplop berisi kartu, tantangan dan jawabaan yang diberikan untuk kegiatan pembelajaran.

Setelah media dibuat, langkah yang dilakukan adalah evaluasi media pada ahli materi. Evaluasi yang dilakukan oleh ahli materi memperoleh kriteria sangat baik. Penilaian ini 
dilakukan dengan satu kali dengan hasil penelitian sangat baik untuk diterapkan.

Keempat, adalah tahap uji coba awal. Pada tahap ini media Papan Putar Nusantara diujicobakan dalam pembelajaran di kelas. Hasil pada tahapan ini adalah layak. Guru sebagai pelaksana pembelajaran menyatakan bila penggunaan media Papan Putar Nusantara membuat pembelajaran menyenangkan, siswa lebih aktif, sehingga pembelajaran tidak monoton, namun ukuran media pembelajaran perlu dibesarkan.

Kelima, adalah tahap revisi produk. Pada tahapan ini dilakukan revisi produk sesuai dengan hasil evaluasi pada tahap uji coba awal. Perbaikan yang dilakukan adalah membuat media Papan Putar Nusantara dengan ukuran yang kebih besar, karena produk sebelumnya dirasakan terlalu kecil.

Keenam, adalah tahapan uji coba lapangan utama. Uji coba lapangan utama dilakukan dalam pembelajaran IPS yang melibatkan guru dam siswa kelas IV SDN Cijoho dan SDN 2 Kiarajangkung. Pembelajaran dilakukan dengan menggunakan media papan Putar Nusantara sebagai media pembelajaran. Pada tahap ini juga guru dan siswa diberi pemahaman tentang tata cara penggunaan media, serta kesesuaiannya dengan materi ajar.

Ketujuh, adalah tahapan revisi produk akhir. Setelah media Papan Putar Nusantara digunakan dalam tahap uji coba utama dan mendapatkan umpan balik kedua, maka dilakukan penyesuaian berdasarkan umpan balik. Berdasarkan hasil uji coba utama, guru menyatakan bila media telah layak digunakan. Media pembelajaran bisa memberi suasana baru dalam elas, sehingga pembelajaran dirasakan menyenagkan dan tidak monoton. 
Kedelapan, adalah hasil uji coba pelaksanaan. Uji coba pelaksanaan lapangan melibatkan 2 guru kelas IV. Peneliti terlebih dulu memperkenalkan dan menjelaskan langkahlangkah penggunaan media mengenalkan dan menjelaskan cara menggunakan Papan Putar Nusantara kepada guru kelas IV. Guru sangat senang dengan melihat kegiatan pembelajaran dengan media permainan, dengan mempraktekan atau memberi contoh bermain kepada guru kelas IV. Uji coba pemakaian dilakukan dengan melaksanaka penggunaan media Papan putar Nusantara dilaksanakan selama 2 kali percobaan bertujuan untuk memberikan inovasi media pada pembelajaran IPS di kelas IV agar guru dapat melaksanakan penggunaan media yang telah dikembangkan oleh peneliti.

Kesembilan, yaitu penyempurnaan produk.pada tahap ini dilakukan perbaikan produk media berdasarkan hasil yang didapat pada penelitian pada pengembangan berupa Produk yang dibuat bernama Papan Putar Nusantara Sasaran media ini adalah peserta didik kelas IV SD Isi dari media ini adalah materi tentang keragaman pakaian adat di indonesia dengan memvisualkan pakaian adat setiap daerah di indonesia. Papan putar Nusantara dapat digunakan sebagai media pembelajaran pada mata pelajaran IPS. 


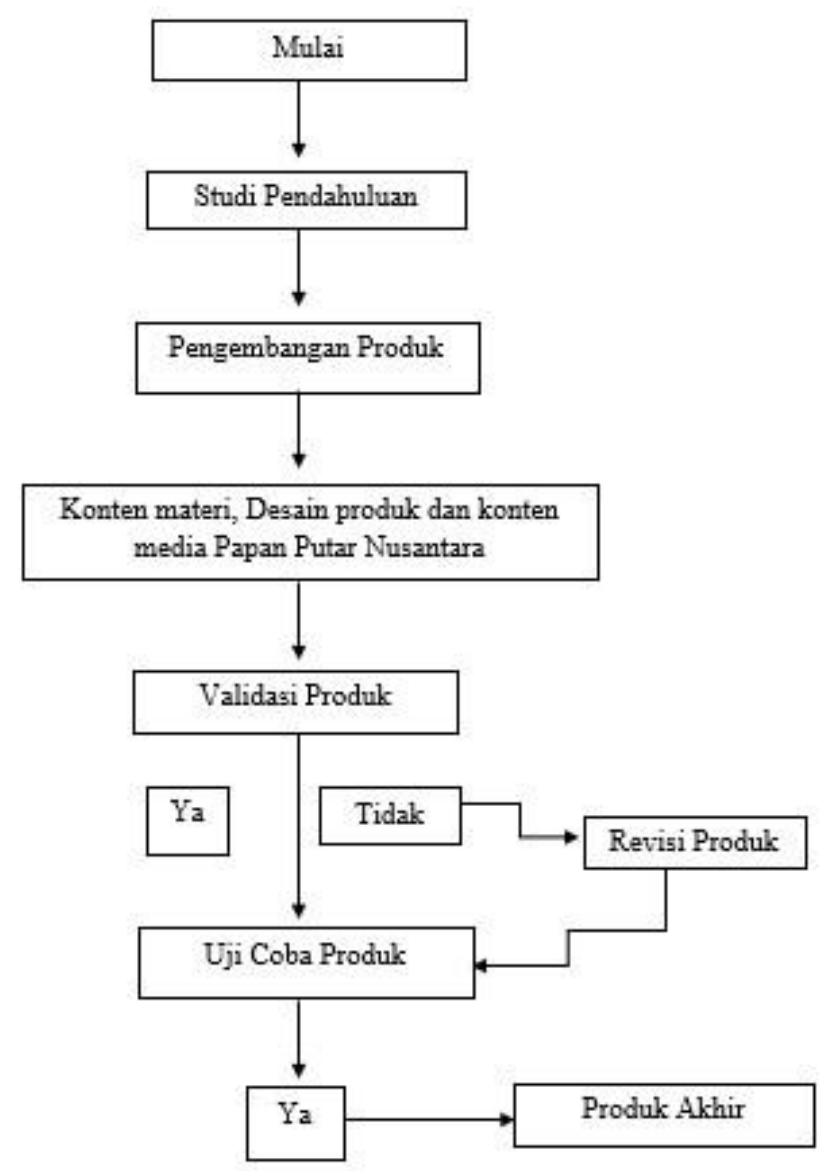

Gambar 2

Diagram Prosedur Penelitian Berdasarkan Model Reeves

Pada tahap akhir pengembangan media, didapati kesimpulan bila media Papan Putar Nusantara adalah media yang layak digunakan sebagai salah satu media pembelajaran IPS. Guru menyatakan bahawa media Papapn Putar Nusantara untuk kelas IV Sekolah Dasar pada pembelajaran IPS sudah layak untuk digunakan dalam pembelajaran di Kelas IV Sekolah Dasar.

Kekuatan utama yang dimiliki oleh media pembelajaran ini adalah pada bentuk pakaian adat dari berbagai daerah yang unik, menarik, serta dengan warna-warni yang menarik. Selain dapat digunakan dalam proses pembelajaran secara klasikal oleh semua siswa dalam kelas secara bersamaan, media Papan Putar 
Nusantara juga dapat digunakan untuk pembelajaran berkelompok karena mudah digunakan dan praktis sehingga peserta didik dapat mengenalkan dan melestarikan berbagai macam keragaman pakaian adat di Indonesia.

Media Papan Putar Nusantara terbuat dari kardus, sehingga mudah disimpan dan dibawa kemana saja. Ukuran tidak terlalu besar, serta ringan untuk dipindahkan dari tempat sat uke tempat yang lain. Selain itu, materi pembelajaran juga mudah diingat karena disajikan dalam bentuk gambar yang didesain secara menarik.

Media Papan Putar Nusantara berbentuk papan kardus lingkaran yang dapat diputar, didalamnya terdapat angka-angka sebagai titik tumpu untuk menentukan hasil dari keterangan pada suatu daerah untuk mengetahui tujuan pembelajaran dengan permainan. Berdasarkan serangkaian proses pengembangan media, peneliti juga menemukan kekurangan dari media ini. Dari segi ukuran, media Papan Putar Nusantara haruslah dibuat dalam ukuran yang cukup lebar sehingga mengakomodir semua siswa yang ada di kelas.

Secara keseluruhan media Papan Putar Nusantra dikategorikan baik dan layak digunakan pada pembelajaran IPS di kelas IV Sekolah Dasar. Dengan mengalami perubahan dalam pembuatan karena hal ini melalui tahapan revisi dari ahli dan uji coba. Pada akhirnya media Papan Putar Nusantara memiliki beberapa komponen yaitu Papan puatar, amplop, alas, kartu, aturan permainan, kartu tantangan.

Revisi akhir dilakukan saat pelaksanaan uji coba penggunaan media, efektivitas media mencapai efektif dan menarik perhatian jika langsung dipraktikkan kepada peserta didik. Penggunaan media papan putar nusantara mendapat 
penilaian berdasarkan baik dan dapat digunakan sebagai salah satu media arternatif dalam menyampaikan materi keragaman pakaian adat di Indonesia.

\section{Kesimpulan}

Media pembelajaran IPS di sekolah-sekolah dirasa masih kurang karena berbagai keterbatasan. Media Papan Putar Nusantara dikembangkan berdasarkan permasalahan yang ada di sekolah. Proses pengembangan media Papan Putar Nusantara dilaksanakan dalam beberapa langkah, yaitu perancangan komponen media, desain permainan, serta pembuatan kartu tantangan dan jawaban, alas, dan amplop. Tampilan pada media papan putar nusantara dibuat pada Gravit Designer untuk mengahasilkan cetakan pada permainan papan dan kartu. Diproduksi media papan putar nusantara berupa papan lingkar yang berputar didalamnya terdapat angka sebagai titik tumpu untuk menentukan hasil dari keterangan pada suatu daerah untuk mengetahui tujuan pembelajaran dengan permainan. Media pembelajaran menjadi faktor untuk meningkatkan pemahaman peserta didik sebagai proses belajar mengajar akan elbih efektif dan menyenangkan sehingga guru membantu mencari pesan dari bahan pembelajaran kepada peserta didik.

Setelah dilakukannya pengembangan media Papan Putar Nusantara. Peneliti menyampaikan saran terkait pengembangan dan penggunaan media ini. Bagi peneliti lain untik dapat lebih lanjut untuk dilkukan penelitian untuk mengetahui peserta didik dalam menggunakan media. Bagi sekolah untuk dapat memaksimalkan pada penggunaan media papan putar nusantara. Bagi guru-guru IPS untuk dapat memanfaatkan 
Devia Luthfi Oktaviani, Sumardi, Akmad Nugraha

media Papan Putar Nusantara, dan dapat dikembangkan dengan menggunakan materi pembelajaran lainnya. Berdasarkan hasil peneliti telah dibahas dapat mengacu pada tindakan praktis, dan pengembangan teori baru dan penelitian lanjutan.

\section{Daftar Pustaka}

Arsyad, A. (2016). Media pembelajaran. Jakarta; PT. Rajagrafindo Persada.

Afandi, R. (2011). Integrasi Pendidikan Karakter Dalam Pembelajaran IPS Di Sekolah Dasar. PEDAGOGIA: Jurnal Pendidikan, 1(1), 1(1), 85-98. https://doi.org/ 10.21070/pedagogia.v1i1.32

Dendi, T. S. \& Sukirno. Pengembangan Media Pembelajaran IPS Dengan Te,a Pemanfaatan Dan Pelestarian Sungai Untuk Siswa Kelas VII SMP. Harmoni Sosial: Jurnal Pendidikan IPS, 2(2), 116-124. https://doi.org/10.21831/hsjpi.v2i2.7663

Fakih Samlawi dan Bunyamin Maftuh. 1998/1999. Konsep Dasar IPS. Jakarta: Dekdikbud. Ditjen. Pendidikan Tinggi Proyek Pendidikan Guru Sekolah Dasar.

Lidinillah, D. A. M. (2012). Educational Design Research: a Theoretical Framework for Action. Tasikmalaya: Universitas Pendidikan Indonesia - Kampus Tasikmalaya.

Rudy, S. \& Hisbiyatul, H. (2017). Media Pembelajaran. Jember: Penerbit Pustaka Abadi

Sapriya. (2009). Pendidikan IPS. Bandung: Rosda Karya.

Sapriya., Istianti, Tuti., \& Zulkifli, Effendi.2007. Pengembangan PendidikanIPS SD. Bahan Belajar Mandiri.Bandung: Fakultas Ilmu PendidikanUPI. UPI Press

Setiawati, T., Pranata, O. H., \& Halimah, M. (2019). Pengembangan Media Permainan Papan pada Pembelajaran IPS untuk Siswa Kelas V Sekolah Dasar. PEDADIDAKTIKA: Jurnal Ilmiah Pendidikan Guru Sekolah Dasar, 6(1), 163-174.

Sugiyono.(2015). Metode penelitian pendidikan. Bandung: Penerbit Alfabeta. 
JIPSINDO, No.2, Vol.7, September 2020

Susanto, Ahmad. 2014. Pengembangan Pembelajaran IPS Di Sekolah Dasar. Jakarta: Prenada Media Group.

Ool, J., \& Laubscher, D. (2016). Design-based research : is this a suitablemethodology for short-term projects ? Educational Media International, 3987(Februari), 1(11). https://doi.org/10.1080/09523987.201 6.1189246 